Article

\title{
Something Wicked Westward Goes: Fanny Van de Grift Stevenson's Californian Uncanny
}

\section{Robyn Pritzker}

Department of English, School of Literatures, Languages, and Cultures, University of Edinburgh, Edinburgh EH8 9JU, UK; v1rpritz@ed.ac.uk

Received: 26 April 2020; Accepted: 25 May 2020; Published: 29 May 2020

check for updates

\begin{abstract}
This essay offers a first critical reading of American author Fanny Van de Grift Stevenson's short story "The Warlock's Shadow" (1886), asserting that the tale appropriates historical traumas in order to navigate, and transgress, boundaries of genre and gender. The strangeness of the text's Central Californian setting, to the narrator, precipitates a series of Gothic metamorphoses, and "The Warlock's Shadow" engages with this transformation via a concept that this essay defines as the "Californian Uncanny". The latter framework is a result of the specific, layered indigenous and colonial identities of post-Gold Rush California coming into contact with the unstable subjectivities of the Gothic genre. "The Warlock's Shadow" manifests the Californian Uncanny primarily through the relationship between the home, the environment, and the "unassimilable" inhabitant. Stevenson's text illustrates, through these images, the ways in which late-nineteenth-century American Gothic fiction has allowed the white feminine subject to negotiate her own identity, complicating the binary distinctions between Self and Other which underpin American colonialism both internally and externally. The phenomenon of the Californian Uncanny in "The Warlock's Shadow" reflects these gendered and geographical anxieties of American identity, confronting the ghosts of the nation's westernmost region.
\end{abstract}

Keywords: US American Gothic; nineteenth-century literature; US American colonialism; US American women's literature; uncanny short fiction; Californian literature; Fanny Van de Grift Stevenson; domesticity; US American identity; late nineteenth century short stories

\section{Introduction}

Between the years of 1878 and 1899, American author Fanny Van de Grift Stevenson published nine short stories in magazines such as Belgravia, Lippincott's, and Scribner's. Stevenson wrote Gothic tales of ghosts, otherworldly realms, and the traumas of femininity, with psychological subtexts regarding identity, loss, and death. She has been scrutinized in multiple biographies, and several fictionalized accounts as recently as 2014, yet, this essay marks the first instance of critical analysis of her fiction. Stevenson's work was influenced in content by her experiences raising children in mining camps in the American West, and in context by her global travels and affiliations with various authors. She does not qualify as a "forgotten voice" of women's literary history, as virtually everything about Stevenson's life is known through her marriage to Robert Louis Stevenson-her writing has simply been left unacknowledged. Yet, her work bends norms as an exemplification of the Gothic genre's potential for renegotiating otherwise rigid boundaries of selfhood.

Published in 1886 in Belgravia, a magazine edited by Mary Elizabeth Braddon, Stevenson's story "The Warlock's Shadow" invokes common features of the nineteenth-century Gothic tale, against the backdrop of a post-Gold Rush Californian landscape. Leaning dually on the Gothic genre and palimpsestuous Californian identities as a tool for redefining expectations for feminine protagonists, the story employs Gothic tropes such as, to reference one list of the genre's traits, "ghosts, magic, and 
blood" (Miller 2012, p. 144), as well as unstable boundaries between psychological imbalances and truly paranormal occurrences. Stevenson's tale opens onto a nameless narrator, "young, romantic, poor, and friendless" traveling west via train to California, to take a job as a teacher after the "death of the last of [her] family" (p. 29). After a distressing, macabre accident in the desert, the narrator settles in Monterey with new friends, Alberto and his aunt, Señorita Rodriguez, although the narrator is still suffering a "painful nervous fever" due to her experience (p. 36). She begins to recover, until she must testify against the man ostensibly responsible for her malady, Manuel, a mixed-race rancher. On the day of the trial, Manuel curses the narrator with a "menacing gesture," throwing her into a "great nervous depression," and causing her to see a shadow, almost but not quite in the form of Manuel, passing in through her window every night. Finally, Dolores, a 120-year-old indigenous woman deemed by the community to be a "witch" agrees to help the heroine (p. 41). Several days pass and Dolores teaches the narrator about the otherworldly, explaining what must be done to undo Manuel's curse. However, Dolores dies the next night, just before the phantom passes through the window. The narrator, "with the strength of madness," takes a dagger from Dolores's hands and plunges it into the specter (p. 48). The next day, Manuel is found dead in his prison cell, "with a knife-wound in the heart" (p. 48). The narrator recovers, marries Alberto, and her new family continues to live in peace henceforth. What arises in "The Warlock's Shadow" is a phenomenon I will describe as the Californian Uncanny, an aesthetic that reflects the redoubled anxieties of history and identity undermining the United States's westernmost boundary.

The nineteenth-century American West is often drawn as an inherently individualistic masculine space, full of danger, yet Stevenson's story indicates a feminine literary identity present and accounted for in California at that time. Masculinity was a tool with which Californian settlers could write themselves a fresh history, control the narratives about their environment, and "define the [Gold Rush] retrospectively as something other than a time of disruption and trauma" (Witschi 2015, p. 76). These rewritings opposed the destructive, colonizing white masculinity which was the reality of Manifest Destiny. In adventure literature of this era, journeying, and "life in unknown realms" were "ideal motifs to strengthen and revitalise ... heroic masculinity" (Zulli 2011, p. 60), and so that heroism became a defining quality of writing in the American West. Frederick Jackson Turner's Frontier Thesis solidified this myth of masculinity, but ultimately acted more as "cultural symptom than fact" (Eperjesi 2005, p. 27). Significant amounts of Californian writing was, in fact, by and about women. Their portraits of homesteading life captured the everyday, and built new conceptions of home, of what a new Californian domesticity, less strictly governed by prescriptive gendered expectations, might look like.

The textual effect of the uncanny and the Gothic mode, which often appear together but are not synonymous, take advantage of the porous constructs of gender, history, and identity found in post-Gold Rush California. "The Warlock's Shadow" engages with the uncanny via the unstable balance between Self and Other. Freud's 1919 essay on the uncanny has been central to readings of the Gothic for a full century, but the definition which this article employs is based on Itzhak Benyamini's updated, reformatted conception of the uncanny, inspired by Freud, Jentsch, and Lacan but adapted to more nuanced twenty-first-century understandings of gender and psychology. Benyamini succinctly explains that uncanniness emerges out of the "opposition of the known and the strange," it is the "uncertainty produced when we are faced with something both known and completely new" (Benyamini 2016, p. 72). Leading away from rigid theories of sexual difference, Benyamini alludes to Donna Haraway's cyborg theory in asserting that the uncanny "tries to break up the possibility of binary thought about the relation between masculine and feminine," often inspiring a type of anxiety (p. 85). In "The Warlock's Shadow," the difference between that which is known and that which is strange is not immediately discernible, and the effect of the uncanny appears alongside common tropes from the mode of the Gothic. As a text which subscribes to many patterns common to the American Gothic, Stevenson's story is nonetheless unique given its regionally specific historical spectropias. 
Much like the Settler Gothic and the Frontier Gothic, which have both also been identified as literary aesthetics of (usually) North American internal colonization, the Californian Uncanny of Stevenson's tale features a "cultivation of often-unstable border zones, of hazy demarcations between self-reliance and self-delusion, between the humane and the monstrous" (Wynn Sivils 2013, pp. 92-93), and is built upon "intersecting borderlands and failed repression, of a haunted national psyche" (p. 85). The literary origin of the Settler and Frontier Gothic subgenres is the captivity narrative, in which a "combination of racial oppression, violence, and the American environment resulted in a harrowing psychological landscape" (p. 90). Yet, the two are not the same. Frontier Gothic texts do not always include settlement, and Settler Gothic narratives are not always taking place on the Frontier.

Although the Californian Uncanny shares qualities with the Frontier and Settler Gothic, particularly via unstable boundaries and racialized oppression, it is closer to the phenomenon defined by Renée Bergland's The National Uncanny (2002). Bergland posits that the entire United States is, essentially, "haunted because it is stolen" (p. 9). According to John Eperjesi in The Imperialist Imaginary, geographical regions are not "natural givens": they "take shape under specific historical conditions and in relation to particular sets of power relations" (Eperjesi 2005, p. 3). I describe the Californian Uncanny, then, as a result of Bergland's National Uncanny molding itself to one such "particular set" and therefore taking up distinct commentaries, aesthetics, and effects. In "The Warlock's Shadow," regional anxieties stemming from California's multiple recolonizations by various settler populations, represented by the narrator, her Spanish friends, and the indigenous characters, further thwart the efforts to "locate" oneself that are common to the Gothic genre.

Although the American Gothic mode generally, as well as Frontier writing, has been susceptible to an "androcentric bias" due to an emphasis on expansionist masculinity, the Gothic genre has often been "a refuge for women writers and female protagonists" (Soltysik Monnet 2013, p. 218). The dualities of man and nature, in opposition to women and domesticity, are disrupted by the presence of women in the American West, and I, therefore, suggest that the existence of texts such as Stevenson's, and phenomena such as the Californian Uncanny, indicates a space at the crossroads of the Gothic mode and the literature of American internal colonization which allows those same women writers and female protagonists to reckon with their own historical positions and identities in the face of historical anxieties. Stevenson's nameless narrator uses her femininity as a tool for transcending the role of victim, and envisions a new westward-looking future for the (white) feminine American subject. This essay defines, and employs, the Californian Uncanny as a frame through which to interrogate Stevenson's particular renegotiation of nineteenth-century US femininity, which primarily occurs in "The Warlock's Shadow" through images of the home, the environment, and the unassimilable inhabitant.

\section{Results and Discussion}

\subsection{Domesticity}

"The Warlock's Shadow" considers the dynamic between masculinized and feminized spaces, displacing femininity and a sense of domestic comfort from the physical home and shifting it to a more subjective realm. Rather than adhering to socially conventional binaries of domestic and foreign, home and world, the text negotiates its own structures of the domestic. For Stevenson's narrator, the safe and homely is tied to a metaphysical comfort linked to understanding, sympathy, and agency, in relation to both her environment and its inhabitants. Often in Gothic fiction, the decay of a home, and the imminent danger of remaining trapped forever within its walls, indicates also the threat of being subsumed within the limitations of the domestic realm. Kate Ferguson Ellis has thoroughly detailed the Gothic home as a "place of danger and imprisonment" in her 1989 book The Contested Castle (p. x). Ellis elaborates on this Gothic domestic inversion: rather than the home being a safe haven, "evil is thus enclosed in the home and freedom lies in the world beyond it, however dangerous."

Yet, in the United States, a country universally haunted, safety must be an individual, subjective journey. American national hauntings extend to both physical ghosts and psychic ones. In understanding 
Stevenson's engagement with conventions of genre, gender, and national history, this study echoes Amy Kaplan's understanding of the chaotic nature of American identity in the nineteenth century, explored in The Anarchy of Empire (2002), as well as Bergland's The National Uncanny. Both critics see American selfhood as being governed by corrupted constructions of domesticity, and indicate that the American subject is plagued by anxieties about both past repressions and ongoing threats from "the particular darknesses of a ghostly Other" (Bergland 2000, p. 7). This does signify a confusion between interiority and exteriority, but that is precisely the point: there are "contradictions, ambiguities, and frayed edges that unravel at imperial borders, where binary divisions collapse and fractured spaces open" (Kaplan 2005, p. 14). Furthermore, the significance of discussing "domesticity" for Kaplan and Bergland includes the double meaning of both "the space of the nation" and "the familial household," illustrating how home-interior-subjective is inextricable from fluid constructs of world-exterior-objective.

I show "The Warlock's Shadow" to support both notions of inescapable American hauntings and inescapably haunted femininity. I carry the theories forward to assert that Stevenson's text demonstrates the only way to put the hauntings to rest, at least in California, is to better understand and adapt to the uncanny landscapes, and by doing so collapse and diffuse binary frameworks. Borderlands in Stevenson's stories are constantly shifting, but the conventions of the domestic are always linked to evolving forms of femininity. That is, the domestic sphere is enmeshed with femininity, and therefore femininity is a part of all national-domestic hauntings. Indeed, discursively, domesticity and spectrality both also extend to "the interiority of female subjectivity" (Kaplan 2005, p. 43). The nation is home is womanhood, and if that home is haunted, so is American femininity, whether it remains indoors or not.

Houses in "The Warlock's Shadow" display the ambivalence of built structures as signifiers of good or evil, as well as their incompleteness as doubles of the Self. Neither of the two houses in this story, Manuel's and the Señorita Rodriguez's, fully signify the realms of safety or danger. Homes themselves are shown to be only one aspect of the domestic ecosystem which will ultimately provide the narrator a sense of refuge. As Ellis argues, normalcy "must be restored by women's activity, not only within its walls but outside in the world as well" (p. xvi). Both houses, then, are integrated into specific natural environs which form the basis of such outside worlds, Manuel's into the sandy dunes of the desert, and the Señorita's into her garden, with her roses acting as a bridge between interior and exterior.

Manuel's house represents all that is corruptible in the domestic ecosystem-home, environment, and inhabitants-and the sinister energy that does lie within his house is not contained by its walls. The narrator and others seek refuge there after their train crashes in the desert, but they find only danger. Manuel's house evokes "the failed home," domesticity's "dark opposite, the Gothic castle" (Ellis 1989, p. ix). A "great house once, in the days of the Jesuit padres", the structure is now "gone to wreck and ruin" and "eaten, and broken, and crumbled away" (Stevenson 1886, p. 32). The adobe house has an "earthy and gravelike smell"; there are spiders everywhere and a general sense of "dust and decay" prevails (p. 33). Not only does the house neither provide comfort nor safety, but it is barely a building at all, as the very environment seems to be reabsorbing it bit by bit. When the narrator awakens in the middle of the night, she feels the darkness crushing her "like something tangible," and "something warm and wet" from the ceiling comes "drip, drip, drip, down the back of [her] neck" (p. 34). She tells herself it is the long-awaited rain, until "a cold chill [creeps] up [her] spine," and she senses "the same thick odour" of blood that she smelled at the site of the train crash (p. 35). Indeed, it is not rain but blood that covers her, and the narrator, along with her new friends, must immediately flee from Manuel and his Californian iteration of the uncanny castle, in a sequence which illustrates Ellis's claim that the Gothic "foreground[s] the home as fortress, while at the same time exposing its contradictions" (p. xi). Importantly, the escape from this Gothic house made by the narrator and the Señorita is not enough to prevent further danger, even when they return to an otherwise "normal" home.

The inadequacy of built spaces in this text to remain a consistent source of refuge is figured through thresholds, particularly windows and doors, as well as threshold states, such as dreams and 
visions. Both physical and psychic thresholds such as these facilitate uncertainty and unsettledness. The windows in "The Warlock's Shadow", usually ajar, function not as objects of partition but rather as gateways between realms. Everything outside the windows in the narrative-scents, sounds, images - eventually finds a way to reach what is inside, and the opposite is also true. The most apparent example of Manuel's phantom aside, the roses outside the Señorita's house also seem to act as an external image of the narrator's state as she lies within. At first, the presence of the roses all around the house is pleasant, and the air, "saturated with the scent of Castilian roses", brings the narrator peace (p. 36). As she fades in strength, so does the aspect of the garden, until "the sickly scent of the rose leaves mingle[s] with an indefinable, slightly sweet, slightly pungent odour, that [she] vaguely remember[s] to have heard of as the precursor to death," and which eventually "impede[s] [her] respiration" (p. 47). From the windows of the Señorita's house, the narrator can see across the road and into the jail where Manuel is held, and thus even the "neglected garden of roses" and all their thorns which stand beyond the window is a more effective protective barrier than the built thresholds of the home (p. 38). Windows, doors, and walls cannot keep anything in or out in this tale, signaling a failure of the house to preserve settlement.

The narrator's sense of safety returns only through learning and adapting, rather than through finding physical refuge, because the houses themselves fail as the source of such security. When the narrator and her friends escape into the Monterey desert, it seems at first that they have fled the danger, and in doing so have enabled "the heroine to purge the infected home and to establish a true one" (Ellis 1989, p. xii). The narrator settles into her new home, she and Alberto fall in love, and for a moment it seems this new domestic serenity has corrected the Gothic disarray of Manuel's adobe abode. However, the initial binary of homely-unhomely which is at first grafted onto constructed spaces is shifted to psychic ones, as it becomes clear the narrator is being haunted in some way by her experience with Manuel, possibly by an actual curse, which follows her into her home and her body, causes her physical pain and anguish, brings on a depression and night terrors, and is otherwise destructive. The learning and adapting the narrator must undertake to break the spell comes mostly through her relationship with 120-year-old Dolores, to whom the three friends turn for help. Dolores is drawn as effectively a part of the Californian landscape herself, emphasizing the blurred boundaries between house, inhabitant, and environment within a domestic ecosystem.

The quest for order and settlement in the story cannot be fulfilled either through negotiating the built environment or one's psychic space: only through navigating and understanding the entirety of her habitat, Self, home, and environment, does that resettlement occur. The Gothic genre works to "subvert the idealization of the home, and by implication the ideology of 'separate spheres' on which that idealization depends" (Ellis 1989, p. xiii). By relegating the houses in the story to liminal structures that belong neither to the distinct realms of house or exterior world, "The Warlock's Shadow" questions not only gendered norms of spatiality, but also the difference between interior and exterior altogether. For the narrator of "The Warlock's Shadow" to settle into a peaceful life, free from destructive forces, she must also be able to occupy what is traditionally considered a masculine space of agency, in order to understand her whole ecosystem enough to control it, both at home and in the environment beyond.

\subsection{Environment}

Stevenson's writing uncouples the historically-bound woman-and-home duality which often underpins the uncanny as a psychoanalytical construct and the Gothic as a genre. I contest her stories indicate the relevance of "woman plus habitat," a slightly expanded manipulation of the defining image of the Female Gothic, "woman-plus-habitation" (Wallace and Smith 2009, p. 47). Rather than domesticity representing anxieties of being a home, as in childbirth, or being trapped within a home, as in a claustrophobic marriage, Stevenson's text suggests that the relationship between a woman and her environment may be equally prone to hauntings. Linda Nash has argued that white settlers felt they needed to "read and to adapt to, rather than simply to conquer" the Central Californian landscape (Nash 2003, p. 26), and thus interpreting Stevenson's stories through a "domestic ecology" invokes 
this more environmental and relational system of symbiosis instead of relying on one body or one identity. The shared ecology of the "home" is here understood to be the place where a character or family/community feels safe, at ease, and settled (in the many senses of the word). A tension between this sense of security and threats from the external environment forms the basis of the domestic ecosystem of "The Warlock's Shadow". In this case, the Californian Uncanny, formed by multiple layers of historical trauma, manifests a villain who represents that exteriority, and cannot be domesticated by white femininity, or at least, cannot be settled.

The source of domesticity (in this case synonymous with the narrator's affective settlement) is adaptation and integration with environment, rather than relying on specific walls and structures for self-containment and self-definition, and the Californian landscape is the fundamental aspect of that habitat. From the first scene of the story, the narrator learns to understand her environment through engagement with locals, making new friends who inform her future mastery of her surroundings. Typically, a female Gothic heroine "reclaims the enclosed space that should have been a refuge from evil but has become the very opposite" (Ellis 1989, p. xiii). "The Warlock's Shadow", however, moves this reclamation outdoors, linking femininity, domesticity, and the landscape in a way that transforms the pattern Ellis identifies. Rather than banishing evil from inside a house, the narrator of this story gradually learns enough about her natural environment to grant her a new sense of agency in defeating the threatening forces around her, which emerge as specters of the region's historical traumas. Indeed, both Manuel and Dolores, as argued above, represent through their indigeneity the sublime mysteries of the environment, or at least knowledge of the land which is not immediately accessible to the white narrator. "The Warlock's Shadow" requires the narrator to acclimatize to her unfamiliar surroundings before she can save herself from danger.

Shifting relationships with the natural environment in the opening of "The Warlock's Shadow" foreshadow the narrator's transformation throughout the tale: the mysterious, "dreary and depressing" terrain of the desert is illuminated through sympathy (Stevenson 1886, p. 30); once the heroine takes agency over learning about the environment, she is no longer afraid of it and she may evolve and progress. Nash writes of the way white settlers perceived "the unhealthful qualities of the Central Valley landscape ... its strangeness and unwholesomeness impressed itself upon both American and European observers" (Nash 2003, p. 34), but when this narrator integrates herself into her surroundings, that uncanniness fades away. She learns from the people she meets, Alberto and the Señorita, about landscapes they pass, and through sympathizing with them the terrain "acquire[s] a new interest" and becomes more familiar (Stevenson 1886, p. 29). Fully "absorbed in looking and listening" (p. 30), she sees the "parched hillsides" are desperate for autumn rain, and the country is "barren in the extreme," the climate "altering since the country had been denuded [...] by the rapacity of the Americans" (pp. 29-30). As Alberto describes and explains the countryside to the narrator, she learns about the environment and reconfigures her own identity in relation to her new surroundings, separating herself from the rapacious "Americans" and situating herself for the first time as a Californian.

To further explain the uncanny relationship that regional writing fostered between the mysteries of the natural world and the shifting role of women settlers of the American West such as the narrator of "The Warlock's Shadow", I draw on both Ida Rae Egli and Elaine Showalter, who have offered commentaries on local color writing by nineteenth-century women writers in their respective works No Rooms of Their Own and A Jury of Her Peers (2009). Showalter speaks more generally about the tradition of local color writing by women across the United States, and identifies certain commonalities within the local color genre, such as "prophetic American womanhood" and fascination with the figure of the old woman, the almost-witch, as well as "declining villages as shrines to the past" (p. 187). Dolores fills this role in "The Warlock's Shadow", living in a similar kind of crumbling ruin as Manuel, along "with the ghosts of her past" (p. 42). Dolores, however, represents a sympathetic, educational relationship with the landscape and its history, as opposed to Manuel's threatening and destructive one. Dolores's identity is more stable and grounded than the narrator's-she has a name, for instance, while the narrator does not, she speaks about her history far more than the narrator does, and she 
is a steward of the land. Acting as the "self-appointed guardian" of her community, she resides in her "temple of holy memories, receiving the bare necessities of existence from the impoverished remnant of the great tribe that such a little time since had been as numerous as the shells on the beach." Thus, with all her wisdom and capabilities, Dolores embodies this sibylline, shrine-dweller so notable as a trope within local color literature. She is also a symbol of the narrator's relationship with her environment. A survivor of the same destruction of the terrain that the narrator observes from the train at the beginning of the tale, Dolores's growing intimacy with the narrator coincides with the narrator's increasing confidence and sense of Self.

A sense of potential, of the possibilities as well as the dangers of a land shaped by constant revolt and redefinition, is a fundamental aspect of the local color story, and one which permeates "The Warlock's Shadow". Californian regional literature and the distinctly Californian local color tradition, sometimes termed the Sagebrush School, mix reality and mythology so that characters are often "picturesque," and tales contain an "abnormality" that is "intimately exclusive to California" (Egli 1997, p. xx). Such heterogeneous writing underscores the "intellectual spirit of revolution and personal freedom" which Egli views as a distinct feature of the West Coast: in California, women were able to abandon their "preconceived notions about what [they] should wear, should do, should be" (pp. xiii-xvii). As the narrator abandons her old life and journeys west on a train to Monterey, her story becomes a part of this movement towards liberation.

The "abnormality" of the environment noted by Egli and the recurring prophetic, sibylline imagery which Showalter suggests both identify a conflict in the local color tradition between history and future, femininity and masculinity, as well as the usual and the unusual, and that discord manifests in Stevenson's story as the Californian Uncanny. Nash writes of the way that white settlers perceived the "unhealthful" qualities of the Central Californian Valley; the "strangeness" and "unwholesomeness" of the very terrain itself was discussed often by European-American settlers (Nash 2003, p. 34), and the sickness and fever which the narrator of "The Warlock's Shadow" suffers through could equally be caused by Manuel's suspected curse or the abnormal and unusual climate and environment. This lack of certainty is what provokes an uncanny effect. As the narrator attempts to turn her abnormal surroundings into her new home, "the female realm of domesticity and the male arena of Manifest Destiny" become "intimately linked" and, as Kaplan suggests, the movement of women westward changes the meaning of home to be more inclusive of not just a house, but one's entire environment (Kaplan 2005, p. 19). Home for the narrator of "The Warlock's Shadow" is not architectural, but symbiotic, affective, and linked inextricably with the landscape, rendering Stevenson's tale an example of the local color Sagebrush School and making its characters part of the literary project of defining US regional identity.

Learning from Dolores about how to stop the curse, then, and adapting to unfamiliar histories and community, is eventually the way the narrator guarantees her own safety and "settles" her narrative journey. Turning the strange landscape into the known and familiar, a part of her domestic habitat, the narrator carves out a space for herself not based on a house but on forging a sense of Self and home. Reaching the point of understanding one's surroundings is central to identity development in the Gothic genre; the blending of object and subject "are represented in fiction by reverberating obscurely signifying structures that have to be 'read' by the heroine" (Lloyd-Smith 1989, p. x). Similarly, Ellis advocates for the ability of the Gothic genre to illustrate that the heroine "needs knowledge, not protection from the truth" (p. xiii). In familiarizing herself with her surroundings (people and place), the narrator of "The Warlock's Shadow" is able to save herself and work toward the process of "naming" that David Punter sees as core to the American Gothic (Punter 2013, p. 27), though readers never do learn her actual name. The narrator's search for a stable subjectivity, a domesticity of selfhood, necessitates navigating not only the terrain but also relationships with its inhabitants. 


\subsection{Inhabitants}

The mysticism rendered throughout this story draws on myths of Frontier masculinity, as well as Gothic ambiguities between the supernatural and the fallibilities of human perception. The narrator assumes the conventions of masculine heroism by saving herself from such psychic threats. Manuel and his curse occupy the role of the "foreign body" in the narrator's mind, in her home, and in her community, functioning as the kind of "disembodied shades," as Kaplan calls them, which blur the boundaries between the interior and exterior of the American psyche (p. 26). Manuel's curse also seems to have control over the heroine's dreams, which begin to affect her physical health, further complicating the distinctions between states such as sleep and waking. Invocations of the supernatural in the tale are therefore linked by the tensions between magic, dreams, and madness.

The "great nervous depression" which Manuel provokes in the narrator is initially figured as a result of the fright and trauma she experienced in the desert, but as symptoms of anxiety manifest themselves in more physical, and then eventually more metaphysical and uncanny, effects, the narrator, Alberto, and Señorita Rodriguez must turn away from medical assistance and seek a more ancient and historical regional knowledge through Dolores. The narrator, who is at first "beset by vague and fanciful alarms" of the sort which her friends suggest are consequences of her feminine constitution, has her dreams transform into night terrors, and then to somnambulation: as she sleepwalks, she passes violently through the very rose bushes that earlier appeared to signify domestic refuge, with her skin being "torn by thorns" (p. 38). One night shortly after this, she has a dream that she is "accompanying her own voice on the Señorita's harp, when, to [her] terror, [she becomes] aware that though [her] lips are moving, it is not [she] who [is] singing" (p. 40). Such dreams speak to what Bergland identifies as an aspect of the National Uncanny, the difficulty, across stolen and spectralized landscapes, of knowing "if any perceived other is in fact other, or is merely a projection of the haunted self" (p. 8). This nightmarish severance of the narrator's voice from her body, and by extension the splitting of her identity, symbolizes her dissociation from her environment and reality, as well as representing the uncanny phantoms of that very environment which she must repress to reunite her divided Self.

Alberto and the Señorita strive to reestablish the narrator's domestic settlement, but only within the walls of the house, and not by cooperation with her habitat, which makes their efforts futile. The two implore Dolores to aid the narrator, and the woman acquiesces, but even she at first suggests the narrator is "most likely suffering from the vapours of youth and idleness" (p. 42). The insanity of the narrator is both implied and explicitly suggested at various points throughout the tale, and her symptoms are the same as what would likely at the time have been termed hysteria. However, the truth is revealed when Dolores stands watch in the night, and the two women both see the "impalpable shadow" passing across the chamber, "changing gradually into the appearance of a man's shadow, yet undefinably different and appalling" (pp. 44-45). Finally, the reliability of the narrator is established and the women begin to sympathize and support each other to mutually ensure the banishment of Manuel's uncanny spectral presence.

In processing her trauma through the banishment of Manuel's specter, the narrator largely fails to establish a stable Self, and instead attempts to rebalance her identity through her identification and understanding of Others in the form of Manuel and Dolores. She attempts to cling to a sense of rationality throughout her experiences, although, as she claims, "when the vagueness and mystery of the hour compass us about: then the heart of flesh quakes, and the lessons of reason are forgotten" (p. 46). When Dolores dies in her sleep, clutching the dagger with which she means to destroy Manuel, the narrator must try to instead rely on the lessons the woman has taught her, which involves replacing reason with an alternative wisdom drawn from feminized intuition and history. In her first real act of agency in the whole story, and one that finally fully places her in the role of a conventional American Western protagonist, the heroine plunges the dagger into the shadow herself. The dissociation and silencing that Manuel's curse imposes upon her similarly deconstruct her understanding of Self and Other, and she must quickly learn to adapt to that fluidity in order to survive. This adaptation would be impossible without Dolores, who is figured both as a racial Other "creeping" around the outskirts of 
nearby Carmello, and as the only person in or around Monterey who has a deep enough understanding of the environment to know how to stop Manuel. By the time Dolores visits the narrator, the latter has also learned enough Spanish to communicate with the older woman, and this additional adaptation is revealed to be fundamental to her integration into a new domestic ecology.

The narrator, in her quest for self-definition, represses her own role in the violence the Americans have enacted upon the region, even though her survival is accomplished at the expense of Dolores's life. Bergland sees such "ghosting" of indigenous people as a textual "technique of removal" (p. 4), and to that point, Manuel and Dolores are "buried on the same day" (Stevenson 1886, p. 48). The dual inabilities of both Dolores and Manuel to survive their encounters with the narrator of this tale functions as another textual consequence of the sustained violence of settlers on unceded land. Eugenia DeLamotte has theorized the pathological whiteness at the heart of such narratives in a way that resonates with "The Warlock's Shadow." She affirms the "Gothic suspicion" that the evil Other is ultimately "a projection of the darkness at the heart of whiteness," and argues that this dynamic must be negotiated "completely inside the bounds of an ideology that defines dark people as profoundly "other" to begin with" - that is, within white subjectivity (DeLamotte 2004, p. 27). The narrator's unstable sense of Self is defined almost exclusively by such Others, at first through the "very dark and handsome" Mexican characters the Señorita and Alberto, who become the narrator's family, and then through Manuel and Dolores.

Throughout this story, Manuel as an Other is a product of the "mechanism of projection" which DeLamotte suggests, and which Maisha Wester has also identified as "a casting away and abasing of the inconsistencies within the projectors themselves," such as, in this case, the narrator's lack of stable identity (Wester 2014, p. 162). The narrator projects such racial anxiety onto Manuel in part because his history and characteristics are well-defined while her own are so ambiguous and reliant on denials of history. The narrator begins the story with no identity, no home, and no family, but by the close of the tale she has redefined and resettled herself. She successfully absorbs and appropriates the necessary knowledge, sympathy, and other resources from her habitat to become a fully-formed subject, but in so doing sets in motion events which eventually lead to the deaths of both indigenous characters.

Several racial identities emerge in tension with each other in this story, that of the ostensibly white narrator, assumed because of her projections of darkness onto the other characters; the ambiguous Spanish and Mexican identities of Alberto and his aunt Señorita Rodriguez, which Maria DeGuzmán explores, in Spain's Long Shadow (DeGuzmán 2005), which are complex and often uncanny constructs in their own right; and the indigenous characters Manuel and Dolores, both of whom possess heightened abilities suggesting a preternatural relationship with the environment. Manuel is described as a native Californian, with "Indian blood predominating almost to the exclusion of the Spanish" (p. 33). His many forms of Otherness are emphasized from the outset: he is known to all as a "bad man," with "blue-black hair ... in a tangled mass upon his shoulders," his nose is "high, thin, and hooked," and his eyes "dull black, deeply sunken above the high cheek-bones, ... dar[t] restlessly from side to side in disquieting contrast with the Indian immobility of the rest of his countenance" (pp. 31-33). The narrator emphatically objectifies Manuel in this way at length. Not only is Manuel not white, but he also fails to assimilate into the Spanish identity that Alberto and Señorita Rodriguez represent-even Alberto distances himself from the cowboy, adamant that Manuel's curse is an indigenous one, that "there are no Spanish words like that" (p. 40). Manuel is written with what Carlos Gallego has called an "excessive" and "uncontrollable" difference (Gallego 2014, p. 176), as a Gothic Other who is unsustainably corrupt within the gaze of the narrator, whose white feminine identity attempts to control his, through an eventual violent erasure.

While Stevenson's text does use the ambiguities of the Gothic genre and the uncanny aesthetic to rewrite gender dynamics, there is nonetheless a failure in this story to imagine a Californian identity that is not tied to the destruction of the native populations. In cultural consciousness, "the birth of the American nation and the death of the Native American were as closely related as light and shadow" (Bergland, p. 40). Over time, white settlers "referred to themselves and their culture as indigenous ... 
and in this way cemented their legitimacy, their own increasingly secure sense of moral, spiritual, and cultural belonging in the place they commonly (and revealingly) described as 'new'" (Johnston and Lawson 2007, p. 363). Native lawyer, teacher, and activist, Vine Deloria, Jr. explains one consequence of the narrator's self-indigenizing, "[T]he white man knows that he is alien and he knows that North America is Indian-and he will never let go of the Indian image because he thinks by some clever manipulation he can achieve an authenticity which can never be his" (Deloria 1998, p. xvi). Settler cultures are "liminal sites at the point of negotiation between the contending authorities of Empire and Native" (Johnston and Lawson 2007, p. 370). Anything in nineteenth-century California labeled "new" is inherently involved with erasure and repression; any pretense at starting over anticipates future hauntings. For the narrator of "The Warlock's Shadow", this process comes to fruition in the form of a curse. While the push towards hybridity in this tale in many ways advocates subversion and the breaking down of boundaries, particularly with regards to gender and domesticity, the process also risks participating in what Elleke Boehmer describes in Colonial and Postcolonial Literature, as the "prevailing quality in colonial interpretation of sameness across difference" (Boehmer 1995, p. 53). In overemphasizing hybridity, this story risks a nullification of nuance and diversity. "The Warlock's Shadow" can be read as a story in which magic suspends a young woman in her journey west: she can never truly settle whilst the shadows of the past are still cast, and in this case, those shadows are of real people and communities, as well as personal traumas.

\section{Conclusions}

The narrator, in enacting her final aggression against Manuel, also removes herself from the passivity associated with heroines in need of rescue, stepping instead into the conventionally masculine role of resourceful American Western individualist. Further foiling generic and gendered expectations for the Gothic heroine, the text also manipulates the marriage plot: the narrator does marry Alberto, but the marriage is not what saves her. An additional layer of complexity stems from this familial connection of the narrator and Alberto's uncanny Spanish-American identity, "off-white," as DeGuzmán describes it (p. xxvii). The interweaving of so many identities, languages, and communities within Stevenson's textual California also suggests the need for what Michael Kowalewski has argued is "a newly conceived literary history that emphasizes multilingual, hybridized tropes and forms of intercultural communication" (Kowalewski 1997, p. 10). Stevenson's texts necessitate inclusion within both mainstream and marginal literary histories, as artifacts of what DeLamotte suggests are "documents in the history of racial formation" (p. 19). Drawing on DeLamotte as well as Kowalewski, I argue that "The Warlock's Shadow" is just such a historical document, and that it also functions to interrogate the purpose of invoking "centres and margins in western writing rather than about interdependence, hybridity, and overlap" (Kowalewski 1997, p. 11). As the narrator navigates a less explicit, more adaptive, and feminized form of colonization and conquest in the American West, she simultaneously perpetuates and destabilizes the very hierarchies which hold her character in place.

The Californian Uncanny in Stevenson's tale, then, demonstrates the ways in which, in nineteenthcentury American Gothic fiction, the white feminine subject, in negotiating her own identity, complicates the clear distinctions between Self and Other central to the patriarchal binaries and narratives of American adventurism, expansion, and colonization, both internal and external. Kaplan points to a similar pattern across depictions of the American heroine in this era, observing that she, "as a composite figure, has at least a double function: she feminizes colonial subjects and masculinizes American women" (p. 109). As such a transformative influence, she also suggests myriad other identificatory possibilities, consequently indicating the difficulties of constituting any unified national identity. In "The Warlock's Shadow," the already peculiar natural environment further estranges its inhabitants through the historical ghosts which traverse the terrain. This results in a Californian Uncanny effect which troubles the cultural constructs of the mythic edge of the American West. 
Funding: This research received no external funding.

Conflicts of Interest: The author declares no conflict of interest.

\section{References}

Benyamini, Itzhak. 2016. Woman as Man's Uncanny Object: A Discussion Following Freud and Lacan. The Undecidable Unconscious: A Journal of Deconstruction and Psychoanalysis 3: 67-92. [CrossRef]

Bergland, Renée L. 2000. The National Uncanny: Indian Ghosts and American Subjects. Hanover: University Press of New England.

Boehmer, Elleke. 1995. Colonial and Postcolonial Literature: Migrant Metaphors. Oxford: Oxford University Press.

DeGuzmán, María. 2005. Spain's Long Shadow: The Black Legend, Off-Whiteness, and Anglo-American Empire. Minneapolis: University of Minnesota Press, Available online: http://ebookcentral.proquest.com/lib/ed/ detail.action?docID=310710 (accessed on 16 October 2018).

DeLamotte, Eugenia. 2004. White Terror, Black Dreams: Gothic Constructions of Race in the Nineteenth Century. In The Gothic Other: Racial and Social Constructions in the Literary Imagination. Edited by Ruth Bienstock Anolik and Douglas L. Howard. London: McFarland \& Company.

Deloria, Vine, Jr. 1998. Foreword: American Fantasy. In Playing Indian. New Haven: Yale University Press.

Egli, Ida Rae. 1997. No Rooms of Their Own: Women Writers of Early California. Berkeley: Heyday Books.

Ellis, Kate Ferguson. 1989. The Contested Castle: Gothic Novels and the Subversion of Domestic Ideology. Urbana: University of Illinois Press.

Eperjesi, John. 2005. The Imperialist Imaginary: Visions of Asia and the Pacific in American Culture. Lebanon: Dartmouth College Press.

Gallego, Carlos. 2014. The Gothic in North American "Subcultures". In The Cambridge Companion to the Modern Gothic. Edited by Jerrold E. Hogle. Cambridge Companions to Literature. Cambridge: Cambridge University Press, pp. 174-90. [CrossRef]

Johnston, Anna, and Alan Lawson. 2007. Settler Colonies. In A Companion to Postcolonial Studies. New York: John Wiley \& Sons, Ltd., pp. 360-76. [CrossRef]

Kaplan, Amy. 2005. The Anarchy of Empire in the Making of U.S. Culture. Cambridge: Harvard University Press.

Kowalewski, Michael. 1997. Gold Rush: A Literary Exploration. Berkeley: Heyday Books.

Lloyd-Smith, Allan Gardner. 1989. Uncanny American Fiction: Medusa's Face. New York: Macmillan.

Miller, Kathleen A. 2012. The Mysteries of the In-Between: Re-Reading Disability in E. Nesbit's Late Victorian Gothic Fiction. Journal of Literary \& Cultural Disability Studies 6: 143-57.

Nash, Linda. 2003. Finishing Nature: Harmonizing Bodies and Environments in Late-Nineteenth-Century California. Environmental History 8: 25-52. [CrossRef]

Punter, David. 2013. Gothic, Theory, Dream. In A Companion to American Gothic. New York: John Wiley \& Sons, Ltd., pp. 16-28. [CrossRef]

Soltysik Monnet, Agnieszka. 2013. They Are Legend: The Popular American Gothic of Ambrose Bierce and Richard Matheson. In A Companion to American Gothic. New York: John Wiley \& Sons, Ltd., pp. 212-22. [CrossRef]

Stevenson, Fanny Van de Grift. 1886. The Warlock's Shadow. Belgravia: A London Magazine 59: 29-48.

Wallace, Diana, and Andrew Smith. 2009. The Female Gothic: New Directions. Berlin: Springer.

Wester, Maisha L. 2014. The Gothic and the Politics of Race. In The Cambridge Companion to the Modern Gothic. Edited by Jerrold E. Hogle. Cambridge: Cambridge University Press, pp. 157-73. [CrossRef]

Witschi, Nicolas S. 2015. The Gold Rush. In A History of California Literature. Edited by Blake Allmendinger. Cambridge: Cambridge University Press, pp. 75-87. [CrossRef]

Wynn Sivils, Matthew. 2013. Indian Captivity Narratives and the Origins of American Frontier Gothic. In $A$ Companion to American Gothic. New York: John Wiley \& Sons, Ltd., pp. 84-95. [CrossRef]

Zulli, Tania. 2011. Colonial Transitions: Literature and Culture in the Late Victorian Age. New York: Peter Lang. 